\title{
A set of data on green, ripening and senescent vanilla pod (Vanilla planifolia; Orchidaceae): anatomy, enzymes, phenolics and lipids
}

\author{
Jean-Marc Brillouet ${ }^{1,3 *}$, Eric OdouX ${ }^{1}$, Geneviève ConeJero ${ }^{2}$
}

${ }^{1}$ CIRAD, Persyst, UMR QUALISUD, TA B-95/16, F-34398 Montpellier Cedex 5, France, brillouet@cirad.fr

2 UMR 5004, INRA-CNRSUMII-SUPAGRO, and CIRAD, PHIV, TA/40/02, F-34398 Montpellier Cedex 5, France

3 UMR 1083, INRA, Univ. Montpellier I, F-34000 Montpellier Cedex, France

${ }^{*}$ Correspondence and reprints

Received 6 January 2010 Accepted 05 February 2010

Fruits, 2010, vol. 65, p. 221-235 (C) 2010 Cirad/EDP Sciences All rights reserved DOI: $10.1051 /$ fruits/2010018 www.fruits-journal.org

RESUMEN ESPAÑOL, p. 235

\section{A set of data on green, ripening and senescent vanilla pod (Vanilla planifolia; Orchidaceae): anatomy, enzymes, phenolics and lipids.}

Abstract - Introduction. Mature green vanilla pods accumulate 4- $O$-(3-methoxy-benzaldehyde)- $\beta$ D-glucoside (glucovanillin), which, upon hydrolysis by an endogenous $\beta$-glucosidase, liberates vanillin, the major aroma component of vanilla. Little is known on the spatial distribution of aroma-generating phenolics, and the enzymes responsible for their liberation ( $\beta$-glucosidase) and oxidation (peroxidase). We report here quantitative data with respect to these three components in relation to the anatomy of the pod. Furthermore, the spatial progression of oxidation is shown. Materials and methods. Mature green vanilla pods were analyzed for their contents of phenolics (HPLC), and $\beta$-glucosidase and peroxidase activities by spectrophotometric techniques using $p$-nitrophenyl glucoside and vanillin as substrates, respectively. Lipids were examined under fluorescence microscopy after Nile red staining. Oxidation development was observed on transverse slices of pods. Results and discussion. Phenolics, and $\beta$-glucosidase and peroxidase activities showed gradients of increasing-decreasing concentrations from the stem to the blossom end of pods. The $\beta$-glucosidase activity is distributed in between the placentae, mesocarp, and trichomes in a [7/2/1] proportion while that of peroxidase shows a [38/1] ratio in the mesocarp and placentae, and was absent from trichomes. Oxidation begins from the blossom end in the placentae, progressively invading the mesocarp and moving towards the stem end. Conclusion. The green mature vanilla pod is spatially heterogeneous for its phenolics, and $\beta$-glucosidase and peroxidase activities, its placentae playing an important role in the liberation of vanillin and its subsequent oxidation.

France / Vanilla planifolia / Orchidaceae / vanilla / $\beta$-glucosidase / peroxidase / glucovanillin / vanillin / lipids / oxidation / gradient / mesocarp / placentae / trichomes / xylem

Ensemble de résultats sur la gousse de vanille verte, murissante et sénescente (Vanilla planifolia ; Orchidaceae) : anatomie, enzymes, composés phénoliques et lipides.

Résumé - Introduction. Les gousses de vanille vertes matures accumulent du 4-O-(3-méthoxy-benzaldéhyde)- $\beta$-D-glucoside (glucovanilline) qui, sous l'effet d'une hydrolyse par une $\beta$-glucosidase endogène, libère de la vanilline, le principal composé d'arôme de la vanille. Les répartitions spatiales des composés phénoliques générateurs d'arôme et des enzymes responsables de leur libération ( $\beta$-glucosidase) et oxydation (peroxydase) sont mal connues. Nous donnons ici des résultats quantitatifs concernant ces trois composantes au regard de l'anatomie de la gousse. De plus, la progression spatiale de l'oxydation est illustrée. Matériel et méthodes. Des gousses de vanille vertes matures ont été analysées pour leurs teneurs en composés phénoliques, et activités $\beta$-glucosidase et peroxydase par des techniques spectrophotométriques en utilisant respectivement le glucoside de $p$-nitrophényle et la vanilline comme substrats. Les lipides ont été examinés en microscopie de fluorescence après coloration par le rouge de Nil. Le développement de l'oxydation a été observé sur des coupes transversales de gousses. Résultats et discussion. Les composés phénoliques et les activités $\beta$-glucosidase et peroxydase montrent des gradients de concentrations croissantes-décroissantes de l'extrémité pédonculaire vers l'extrémité florale de la gousse. L'activité $\beta$-glucosidase est distribuée entre placentas, mésocarpe et trichomes dans un rapport [7 / 2 / 1] alors que l'activité peroxydase est répartie dans des proportions [38 / 1] entre le mésocarpe et les placentas ; elle est absente des trichomes. L'oxydation commence dans les placentas de la partie florale en envahissant progressivement le mésocarpe et se déplace vers la zone pédonculaire. Conclusion. La gousse de vanille verte mature est hétérogène d'un point de vue spatial pour ce qui concerne ses composés phénoliques et activités $\beta$-glucosidase et peroxydase, les placentas jouant un rôle important dans la libération de la vanilline et son oxydation consécutive.

France / Vanilla planifolia / Orchidaceae / vanille / B-glucosidase / peroxydase / glucovanilline / vanilline / lipides / oxydation / gradient / mésocarpe / placentas / trichomes / xylème 


\section{Introduction}

Vanilla pod, the fruit of Vanilla sp. vine, exhales an excellent aroma, making it a high added-value product. When it is green mature at the time of harvest (8-9 months after pollination), it does not smell; it is only after a lengthy treatment that it becomes a commercial product. Up until the present day, preparation of vanilla comprises several steps [1-4], "killing" in a hot water bath, "sweating" in a cloth-lined close wooden box, drying on racks in the morning sun, and conditioning in a wax paper-lined wooden trunk, the number and length of the various steps depending on the area of production. Basically, the aims and consequences of these steps are:

- "killing", to stop the vegetative life of the pod to prevent dehiscence [3]; decompartmentation of the inner volumes of the cells (vacuole, cytoplasm, etc.) [5], outset of hydrolysis of glucovanillin by the vanilla $\beta$ glucosidase [6] and of oxidation with production of brown pigments; no variation in the water content [3],

- "sweating", to take benefit of the inner heat generated by the "killing" to go on with hydrolysis of glucovanillin by the vanilla $\beta$ glucosidase [7] and continue oxidation; no variation in the water content,

- "drying", a lengthy step (several months) aiming at bringing pods to 30-50\% dry matter content,

- conditioning, to further increase the dry matter content to $50-60 \%$, depending on its duration.

Commercial pods will have variable vanillin contents depending on origin (country, areas of production, and, for the same origin, variability of the pod batches cured), agropedoclimatic conditions, cultural practices, curing conditions, etc. [1, 8-10].

Although a great amount of work has been done on vanilla for a century, there are still zones of uncertainty concerning the sequence of events leading to the development of the vanilla flavor. The enzymatic release of vanillin from its non-aromatic precursor, glucovanillin, has been established for a long time [1], but it is only recently that the vanilla enzyme responsible was charac- terized [6]; although Arana [1] demonstrated earlier that glucovanillin was unequally distributed along the length of the pod, no fine anatomical picture of its distribution in the different compartments of the pod (mesocarp, placentae, trichomes) was available until recently [11-13]; it is the same in the case of the $\beta$-glucosidase [11].

Oxidative alteration of vanillin has also been known for a long time [1] and is exemplified by drastic color changes occurring during the curing process, the green vanilla pod turning black in the end. Since then several authors have measured the peroxidase activity of vanilla [14-16], and a peroxidase was recently purified and characterized [17]. However, it is only recently that Gatfield et al. [18] showed the presence in some vanilla extracts of a taste-active compound, divanillin, an oxidation product of vanillin by a peroxidase, and no anatomical picture of the distribution of peroxidase activity in the vanilla pod is, to our knowledge, available today.

Thus, the aim of this publication is to gather apparently dispersed data, all of them converging for a better comprehension of the formation of the vanilla aroma. More precisely, objectives were:

- to analyze the variability in populations of green vanilla pods with regard to glucovanillin and $\beta$-glucosidase contents,

- to examine in detail the existence of longitudinal and radial gradients in the pod for $\beta$-glucosidase, peroxidase, phenolics and sugars,

- to describe the anatomical distribution of $\beta$-glucosidase, peroxidase and phenolics in the pod,

- to describe the longitudinal development of phenol oxidation in the pod,

\section{Materials and methods}

\subsection{Plant materials}

Two large batches of green mature vanilla pods ( 8-9 months after pollination) were from Réunion Island (France) and Madagascar; other minor batches were from Tamil 
Nadu (India) and Papantla (Vera Cruz, Mexico). Their mass ranges were 15-20 g. Their water content was determined by drying overnight at $105^{\circ} \mathrm{C}$.

\subsection{Extraction and measurement of the $\beta$-glucosidase activity}

Immediately after dissection [13], portions of mesocarp, placentae and trichomes ( 30$50 \mathrm{mg}$ each) were dilacerated with a MicroTurrax at ambient temperature in $10 \mathrm{~mL}$ of $0.1 \mathrm{M}$ phosphate buffer ( $\mathrm{pH} 7.0)$. After centrifugation $\left(14000 \mathrm{~g}, 5 \mathrm{~min}, 20^{\circ} \mathrm{C}\right)$, the filtrate was diluted $10 \times$ with the same buffer $\left(20{ }^{\circ} \mathrm{C}\right)$.

Activity was measured as described by Odoux et al. [6]: briefly, an aliquot of enzyme extract was added to $200 \mu \mathrm{L}$ of $4 \mathrm{mM} p$-nitrophenyl $\beta$-D-glucopyranoside in the above phosphate buffer and the total volume was made to $400 \mu \mathrm{L}$ with phosphate buffer. After $20 \mathrm{~min}$ of incubation at $40^{\circ} \mathrm{C}, 1 \mathrm{~mL}$ of $0.5 \mathrm{M}$ $\mathrm{NaOH}$ was added and the optical density was read at $\lambda=400 \mathrm{~nm}$. 1 nanokatal (nKat) is defined as the amount of enzyme hydrolyzing 1 nanomole of substrate per second in the above conditions.

Undissected representative portions of pods ( $~ 50-250 \mathrm{mg}$ ) were also submitted to the same extraction-determination protocol.

\subsection{Extraction and measurement of the peroxidase activity}

Immediately after dissection, portions of mesocarp, placentae and trichomes ( 50$100 \mathrm{mg}$ each) were dilacerated with a MicroTurrax at ambient temperature in $1.8 \mathrm{~mL}$ of $0.1 \mathrm{M}$ acetate buffer ( $\mathrm{pH} 4.5)$ containing $1 \mathrm{M} \mathrm{NaCl}$, and the slurry was stirred for $30 \mathrm{~min}$ at ambient temperature. After centrifugation $\left(14000 \mathrm{~g}, 5 \mathrm{~min}, 20^{\circ} \mathrm{C}\right)$, the supernatant $(400 \mu \mathrm{L})$ was mixed with the same volume of buffer, and $200 \mu \mathrm{L}$ of $40 \mathrm{mM}$ vanillin in buffer was added, then $10 \mu \mathrm{L}$ of $30.9 \%$ hydrogen peroxide; the increase in absorbance was followed at $\lambda=480 \mathrm{~nm}$ between ( 1 and 3 ) $\mathrm{min}$ at $20^{\circ} \mathrm{C}$. A unit (U) of peroxidase activity was defined as the amount of enzyme giving a 0.001 absorbance unit increase per minute.
Undissected representative portions of pods ( $50-250 \mathrm{mg}$ ) were also submitted to the same extraction-determination protocol.

\subsection{Extraction and determination of glucovanillin and related phenolics}

When mentioned, the word "phenolics" will include aglycons and their glucosylated forms. Analyses were performed according to Odoux and Brillouet [13]: briefly, portions of mesocarp, placentae and trichomes ( 50 $100 \mathrm{mg}$ each) were extracted with [methanol:water] (50:50, v/v); the supernatant was then submitted to quantitative analysis by HPLC separation of phenolics and their glycoconjugates on a $(250 \times 4.6) \mathrm{mm}$ Modulocart QSLichrospher 5- $\mu \mathrm{m}$ ODS2 column operated at $0.5 \mathrm{~mL} \cdot \mathrm{min}^{-1}$ and $30{ }^{\circ} \mathrm{C}$. The mobile phase consisted of [water:formic acid] (98:2, v/v) (eluant A) and [water:acetonitrile:formic acid] (18:80:2, v/v/v) (eluant B). The elution program was as follows: $8-13 \%$ eluant B for 0-10 min; 13-20\% eluant B for 10-30 min; 20-8\% eluant B for 30-35 min. Duplicate samples were injected at a level of $20 \mu \mathrm{L}$. The column effluent was monitored at $280 \mathrm{~nm}$. Triplicate samples were injected at a level of $10 \mu \mathrm{L}$. External standardization was achieved with pure glucosides, and aglycones. Data were expressed as \% per fresh weight.

Undissected representative portions of pods ( 100-200 mg) were also submitted to the same extraction-determination protocol.

Estimation of "total" vanillin was achieved according to Odoux [3]: "total" vanillin content is that obtained after full hydrolysis of glucovanillin with almond $\beta$-glucosidase plus free vanillin, the latter being generally low in the total. Thus "total" vanillin is an acceptable approximation of the glucovanillin level.

\subsection{Extraction and determination of sugars}

Undissected representative portions of pods ( 40-250 mg) were extracted by $1.5 \mathrm{~mL}$ of $0.01 \mathrm{~N}$ sulfuric acid for $2 \mathrm{~h}$ at ambient temperature, then centrifuged (14000 g, $5 \mathrm{~min}$ ). HPLC analyses were performed using a 
Spectra-SERIES separation system P100 (Thermo Separation Products, USA) including a quaternary pump and controlled by Chemstation A.10.02 software. Separations were achieved using a $(300 \times 7.8 \mathrm{~mm}$ i.d. $)$ AMINEX $^{\circledR}$ Ion HPX-87H (7 $\mu \mathrm{m}$, BioRad) column with a guard column operated at $25^{\circ} \mathrm{C}$. ine mobile phase consisted of $0.01 \mathrm{~N}$ sulfuric acid at $0.6 \mathrm{~mL} \cdot \mathrm{min}^{-1}$. Duplicate samples were injected at a level of $20 \mu \mathrm{L}$. The column effluent was monitored with a Shimadzu differential refractometer. Quantification was achieved by injection of solutions of known concentrations of sucrose, glucose and fructose; data were expressed as \% per fresh weight.

\subsection{Fluorescence microscopy}

Fresh cross-sections $(100 \mu \mathrm{m})$ were obtained from pods using a Microm HM650V vibratome, stained for few minutes with Nile red $\left(0.5 \mathrm{mg} \cdot \mathrm{mL}^{-1}\right.$ acetone, then $1 / 500$ dilution in water), then observed with a Leica DM6000 epifluorescence microscope (filter cube A, excitation 450-500 nm, emission > $528 \mathrm{~nm}$ ) (Leica Microsystems, Rueil-Malmaison, France).

Figure 1.

Distribution of the « total » vanillin content and $\beta$-glucosidase activity amongst two populations of green mature vanilla pods $(\mathrm{n}=70$ and $\mathrm{n}=95$, respectively).

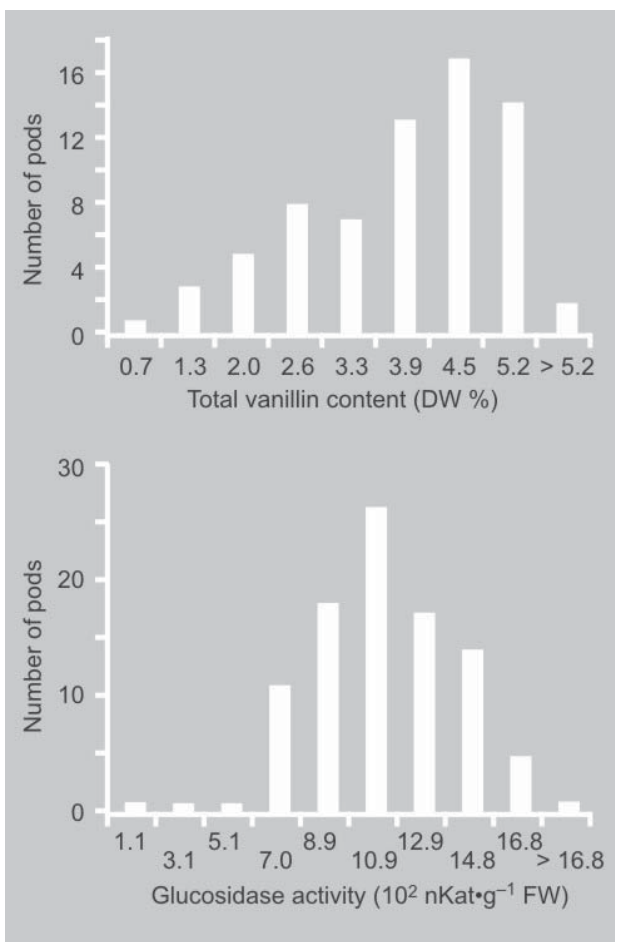

\subsection{Chemicals}

Vanillin and $p$-hydroxybenzaldehyde were from Fluka (Buchs, Switzerland). Glucovanillin was from ChromaDex (Irvine, CA, USA), and glucoside of $p$-hydroxybenzaldehyde was synthesized according to Dignum et al. [19].

\section{Results}

\subsection{Variability in the total vanillin content and $\beta$-glucosidase activity amongst populations of mature green vanilla pods}

Two large batches of mature green vanilla pods were analyzed for their "total" vanillin content and $\beta$-glucosidase activity (figure 1). One must note that the mature green stage was chosen by local producers according to visual estimation of the pods. As seen, this population exhibits a wide variability from $0.7 \%$ to more than $5.2 \%$ of the pod dry weight, with the majority of pods having $4.5 \%$ of vanillin, i.e., $9.2 \%$ as glucovanillin. The same remark may be applied to measurement of the $\beta$-glucosidase activity: indeed, it varied in a second population from $110 \mathrm{nKat} \cdot \mathrm{g}^{-1}$ fresh weight to more than $1680 \mathrm{nKat}^{-\mathrm{g}^{-1}}$ fresh weight.

\subsection{Longitudinal distribution of mass, water, $\beta$-glucosidase, peroxidase, sugars and phenolics in mature green vanilla pods}

After removal of the corky lignified zones of attachment to the stem and residual blossom pieces (3 $\mathrm{mm}$ length), vanilla pods were cut into 16 slices of equal thicknesses from their stem to their blossom end and analyzed (figure 2).

Mass percents and contents of water and dry matter along the length of a mature green vanilla pod show that a pronounced water gradient develops along this axis from the highly hydrated stem end (slices $n^{\circ} 1,2$, $\sim 89.2 \%$ ), descending to $\sim 84.5 \%$ in the drier $\sim 2$ 3-length zone (slice $\mathrm{n}^{\circ} 12$ ); then, water 
content increases up to the blossom end (slice $n^{\circ} 16, \sim 87.8 \%$ ) (figure $2 A$ ). All calculations done, slice $\mathrm{n}^{\circ} 14$, i.e., close to the blossom end, is the most representative of the entire pod water content. The mass distribution follows an almost symmetrical pattern: indeed, the pod shows a tronconic shape from slices $n^{\circ} 1$ to 6 , then adopts a pseudo-cylindrical structure ( $\mathrm{n}^{\circ} 7$ to 15$)$, and finally terminates as a cone $\left(n^{\circ} 16\right)$.

The $\beta$-glucosidase activity exhibits a pattern of variation similar to that of the mass (figure $2 B$ ): actually, it is also somewhat superimposable on the variation in dry matter (figure $2 A$ ). Its distribution in nkatals by 1/3-length portion ( $\operatorname{slices} \mathrm{n}^{\circ} 1$ to $6, \mathrm{n}^{\circ} 7$ to 11 , $\mathrm{n}^{\circ} 12$ to 16 ) was: $22 / 40 / 38$. Peroxidase is differently distributed: from slices $n^{\circ} 6$ to 14 , its level was constant while it increased gently up to the stem end; on the other end of the pod (blossom), it increased tremendously up to the terminal slice $n^{\circ} 16$. Its distribution in units by 1/3-length portion was 31 / 27 / 42. Sugars (i.e., sucrose, glucose and fructose in a constant weight ratio of $0.47 / 0.26 / 0.27$ ) decreased from the stem end to slice $\mathrm{n}^{\circ} 13$, then they increased moderately up to the floral end (figure $2 B$ ).

Variations in the concentrations of glucovanillin and vanillin (\% per FW) show profiles somewhat symmetrical to the water content but slightly shifted (figure 2C). Their levels began from almost nil in the stem end, then progressively climbed up to slice $n^{\circ} 14$, and finally dramatically fell down to the blossom end; this is also true on a dry matter basis, glucovanillin varying from 0.08 (slice $n^{\circ} 1$ ) to a maximum of 9.43 (slice $\left.\mathrm{n}^{\circ} 12\right) \%(\mathrm{DW})$, and vanillin from 0.01 to $0.85 \%(\mathrm{DW})$. The same trends were observed for $p$-hydroxy-benzaldehyde glucoside and its aglycon; however, it must be noted that, while glucovanillin is more or less stable from slices $n^{\circ} 8$ to $15, p$-hydroxybenzaldehyde glucoside goes on increasing from slices $n^{\circ} 10$ to 14 . Weight concentration ratios between glucosides and their aglycones were stable at: [glucovanillin / vanillin $]=11.2, \quad[p$-hydroxybenzaldehyde glucoside $/ p$-hydroxybenzaldehyde] $=5.6$. Distribution of total phenolics (FW) by $1 / 3-$ length portion (slices $n^{\circ} 1$ to $6, n^{\circ} 7$ to 11 , $\mathrm{n}^{\circ} 12$ to 16 ) was: $17 / 43 / 40$.

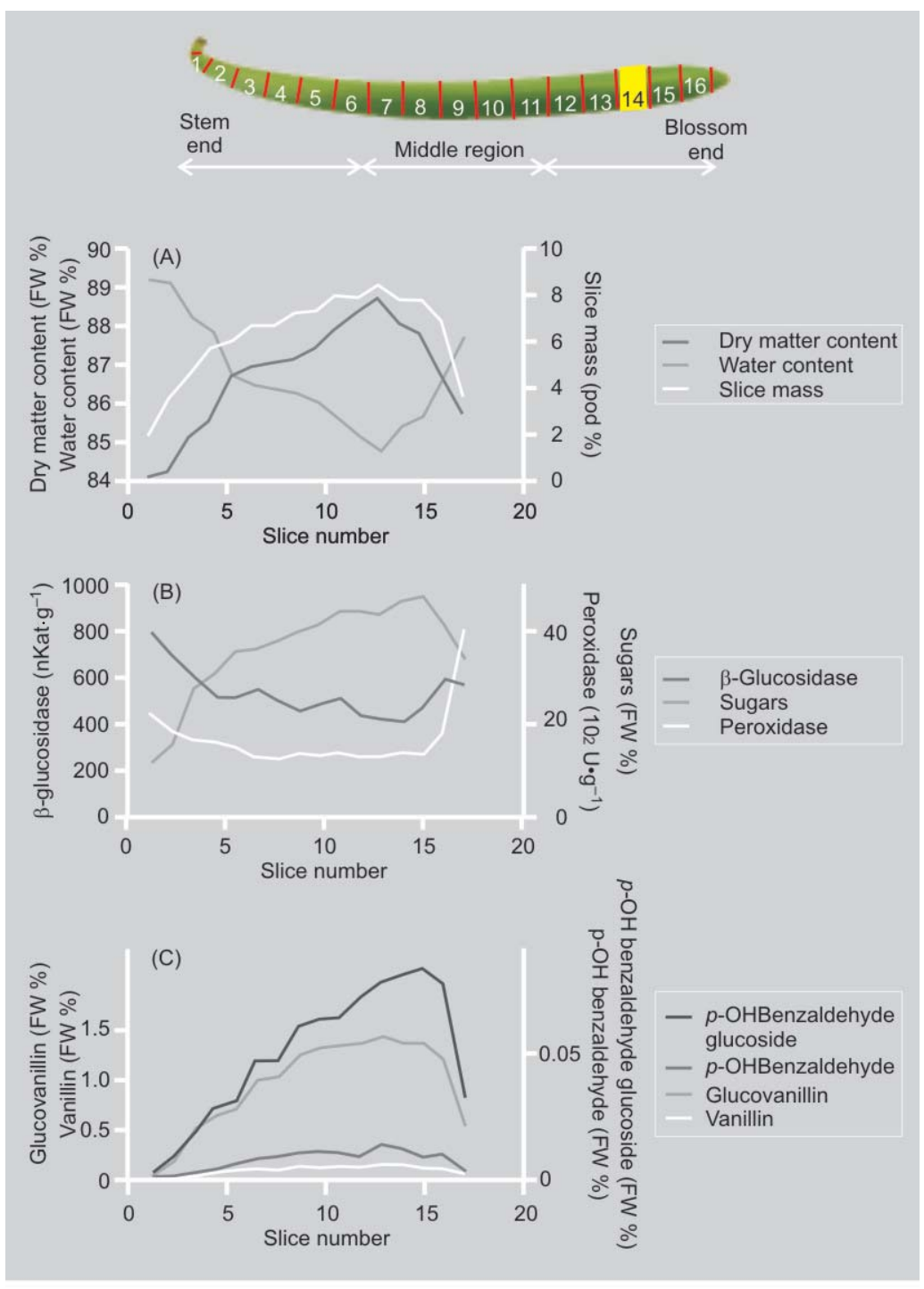

Similar variations were observed on several other green pods of different origins.

\subsection{Radial distribution of $\beta$-glucosidase and peroxidase in the different compartments of mature green vanilla pods}

Transverse slices $\left(\mathrm{n}^{\circ} 14\right)$ of vanilla pods were finely dissected under a stereomicroscope, yielding chlorophyllous mesocarp, placentae and trichomes. The mesocarp portion was further dissected into five concentric coronae [(I) to (V)] and placentae were divided into three layers [(VI) to (VIII)] from their base to their top (figure 3).
Figure 2.

Variations in mass, water and dry matter (A); $\beta$-glucosidase, peroxidase and sugars $(\mathrm{B})$; glucovanillin, p-hydroxybenzaldehyde glucoside, vanillin and p-hydroxybenzaldehyde contents (C), along the longitudinal axis of a mature green vanilla pod. 


\section{J.M. Brillouet et al.}

Table I.

Distribution of the $\beta$-glucosidase and peroxidase activities, and glucovanillin in the different compartments of a transverse slice $\left(n^{\circ} 14\right)$ of a mature vanilla pod $(n=10)$.

\begin{tabular}{|c|c|c|c|c|c|}
\hline Compartment & Compartments & $\mathrm{N}^{\circ}$ & $\begin{array}{c}\beta \text {-Glucosidase activity } \\
\left.\text { (nKat } \cdot \mathrm{g}^{-1} \mathrm{FW}\right)\end{array}$ & $\begin{array}{l}\text { Peroxidase activity } \\
\left(\mathrm{U} \cdot \mathrm{g}^{-1} \mathrm{FW}\right)\end{array}$ & $\begin{array}{c}\text { Glucovanillin }^{2} \\
\text { (\% FW) }\end{array}$ \\
\hline \multirow[t]{5}{*}{ Mesocarp } & Epidermis & (l) & $268 \pm 119$ & \multirow{5}{*}{$7124 \pm 183^{1}$} & \multirow{5}{*}{$0.03 \pm 0.02^{1}$} \\
\hline & Outer mesocarp & (II) & $311 \pm 192$ & & \\
\hline & \multirow{3}{*}{ Inner mesocarp } & (III) & $294 \pm 105$ & & \\
\hline & & (IV) & $326 \pm 177$ & & \\
\hline & & $(\mathrm{V})$ & $210 \pm 123$ & & \\
\hline \multirow[t]{3}{*}{ Placentae } & Placental base & $(\mathrm{VI})$ & $1047 \pm 305$ & \multirow{3}{*}{$186 \pm 9^{1}$} & $9.63 \pm 1.99$ \\
\hline & Lobes of the placentae & (VII) & $1377 \pm 112$ & & \multirow{2}{*}{$4.98 \pm 1.27^{1}$} \\
\hline & Funicles & (VIII) & $1210 \pm 152$ & & \\
\hline Trichomes & Trichomes & $(\mathrm{IX})$ & $200 \pm 89$ & Not detected & $3.93 \pm 1.28$ \\
\hline
\end{tabular}

\section{Figure 3.}

Top: transverse slice of a mature green vanillapod $\left(n^{\circ} 14\right)$ showing the diverse compartments analyzed: (I) epidermis, (II)-(III) outer mesocarp, (IV)-(V) inner mesocarp, (VI) placental base, (VII) lobes of the placentae, (VIII) funicles, (IX) trichomes. Bottom: anatomical distributions of the $\beta$-glucosidase $(A)$, and peroxidase (B) activities, and glucovanillin (C) (from ref. [13]). Intensities of colors (clear to deep) are roughly indicative of numerical values given in table I; white indicates nil.

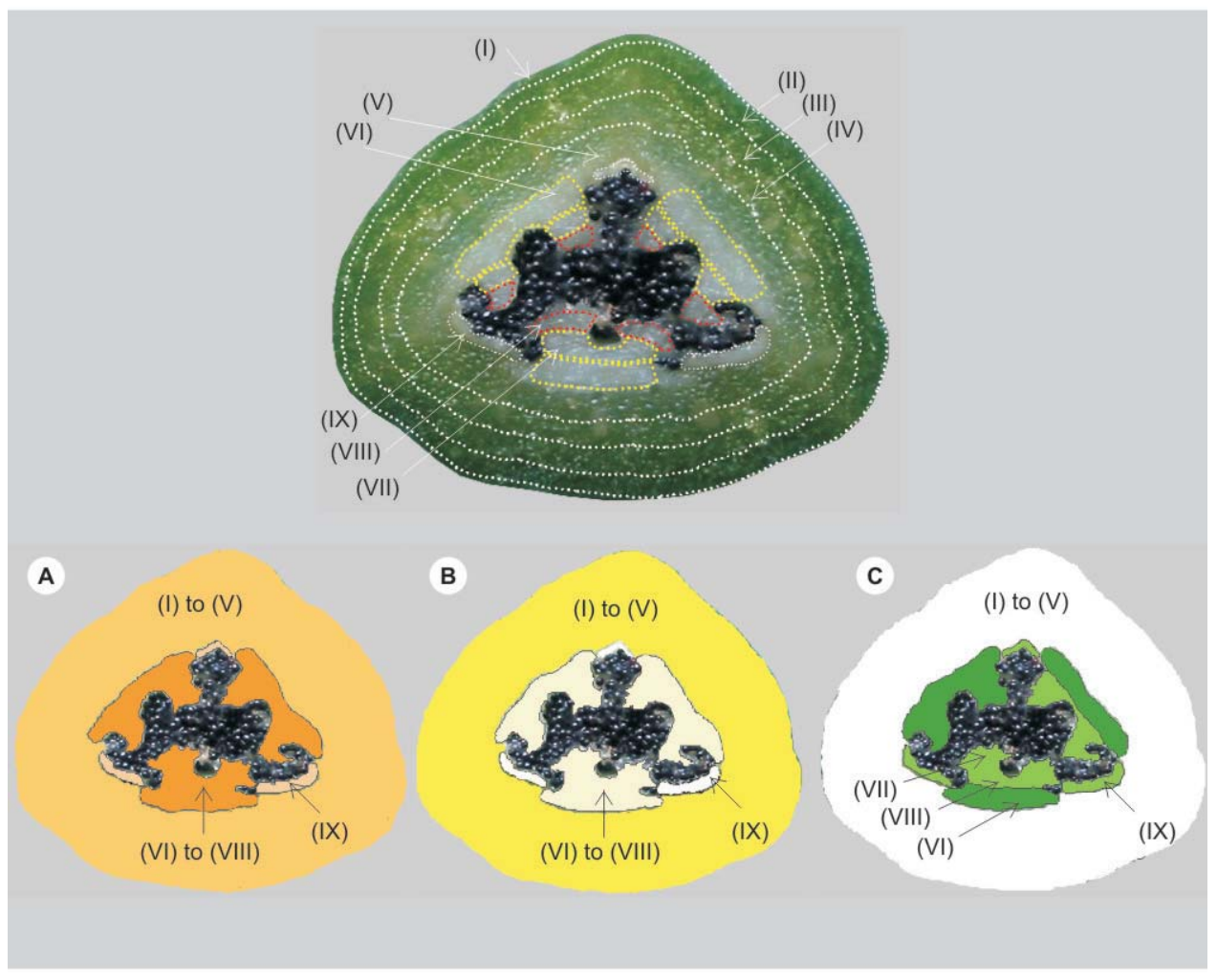


The $\beta$-glucosidase activity was measured onall these fractions including trichomes, while the peroxidase activity was determined on whole mesocarp, placentae and trichomes without sub-dissection (table I; figure 3). The $\beta$-glucosidase was mainly and rather uniformly located in the placentae; mesocarp was 3-4x poorer and no radial gradient was observed from its periphery to its inner portion. Trichomes were the poorest compartment $(1.5 \times$ lower than mesocarp).

The peroxidase activity was differently distributed: it was absent from the trichomes and showed a [38/1] repartition between mesocarp and placentae (FW).

\subsection{Longitudinal and radial developments of oxidation in ripening-senescent vanilla pods}

A ripening-senescent pod clearly shows oxidation at the blossom end progressively invading up to one-fourth of the length where green tissues are still present (figure 4); oxidation is also visible at the stem end ( $\sim 10 \%$ of pod length). Transverse slices were obtained from different regions, starting from the green region and finishing at the blossom end, from the green area $\left(n^{\circ} 1\right)$ to greenish-brown $\left(n^{\circ} 2\right)$, to brownish $\left(n^{\circ} 3\right)$, to blackish $\left(n^{\circ} 4\right)$, to deep black $\left(n^{\circ} 5\right)$ ones. On the fresh green slice, one may see the chlorophyllous mesocarp, the diffuse white placental zone, the glassy white $\mathrm{V}$ - and Jshaped trichome corners, and, on the frozen equivalent slice, a white area clearly demarcating the placentae (see also ref. [11]); the first signs of oxidation resulting from the transverse cutting are visible in the fresh mesocarp portion as two brownish circles, vascular bundles. On fresh slice $n^{\circ} 2$, one sees oxidation superimposed on the placental zone; on the frozen ring, three stages are observed: an intact upper left white placenta, an upper right slightly brown one and below a deep brown one and there, oxidation invaded the mesocarp. On fresh slice $\mathrm{n}^{\circ} 3$, a typical clear reddish-brown urchinlike shape radiating from the placentae outwards half the mesocarp thickness; one must note that no oxidation is visible in between the mesocarpic vascular bundles. In this slice, one may see residual whitish placental zones and the trichomes stay white (see also figure 5). When moving towards the blossom end, slice $\mathrm{n}^{\circ} 4$ shows a more or less regular annulus uniformly stained reddish while trichomes and funicles appear white; half of the mesocarp is still greenish. Finally, on slice $n^{\circ} 5$, one sees that the entire slice, except trichomes and funicles, turned deep chocolate brown.

On the enlarged view of slice $\mathrm{n}^{\circ} 3$ ( $f$ igure 5), one may see that the ends of rays from the radiating shape are actually vascular bundles: three per triangle side, and a triplet at each corner in the outer mesocarp area made of twin little bundles and a larger one (see also figure 4 , slice $\mathrm{n}^{\circ} 2$, and refs. [11, 20]). There, three small bundles are also seen in the whitish upper right placenta. At this stage, one may see that oxidation draws upside-down funnel-like shapes, their bottom being centered on the mesocarpic vascular bundles; areas in between bundles remain yellowish-green.

\subsection{Anatomical distribution of lipids in mature green vanilla pods}

In a partial transverse section of a native mature green vanilla pod after lipid staining with Nile red (figure $6 A$ ), neutral lipid droplets intensely fluorescing in sulfur yellow were seen in the single layer of endocarp cells lining the locule in between the trichomes and bordering the placental laminae (or blades); they were also seen in a single cell layer beneath the trichomes. Whether these two single layers are of the same ontogenic origin remains uncertain, and there is no apparent discontinuity in their junction area; the lipid droplets in the subtrichomal layer, however, appear smaller than in the properly so-called endocarpic layer. The trichomes also contain numerous small lipid droplets. Differently from the two above compartments (endocarp and trichomes), deposits of an intensely golden orange fluorescing substance, not spherically structured in droplets, were also seen in the terminal region of the placental blades, i.e., the funicles. The autofluorescence of the upper part of the placental laminae (lobes) is apparently restricted to the funicular ends (figure $6 B$ ). 


\section{J.M. Brillouet et al.}

Figure 4.

Transverse slices from the stem to the blossom end of a ripening-senescent vanilla pod showing development and progression of oxidation. In pod slice $\mathrm{n}^{\circ} 2$ mesocarpic and placental vascular bundles are underscored (black) (see also refs. [11, 22]).

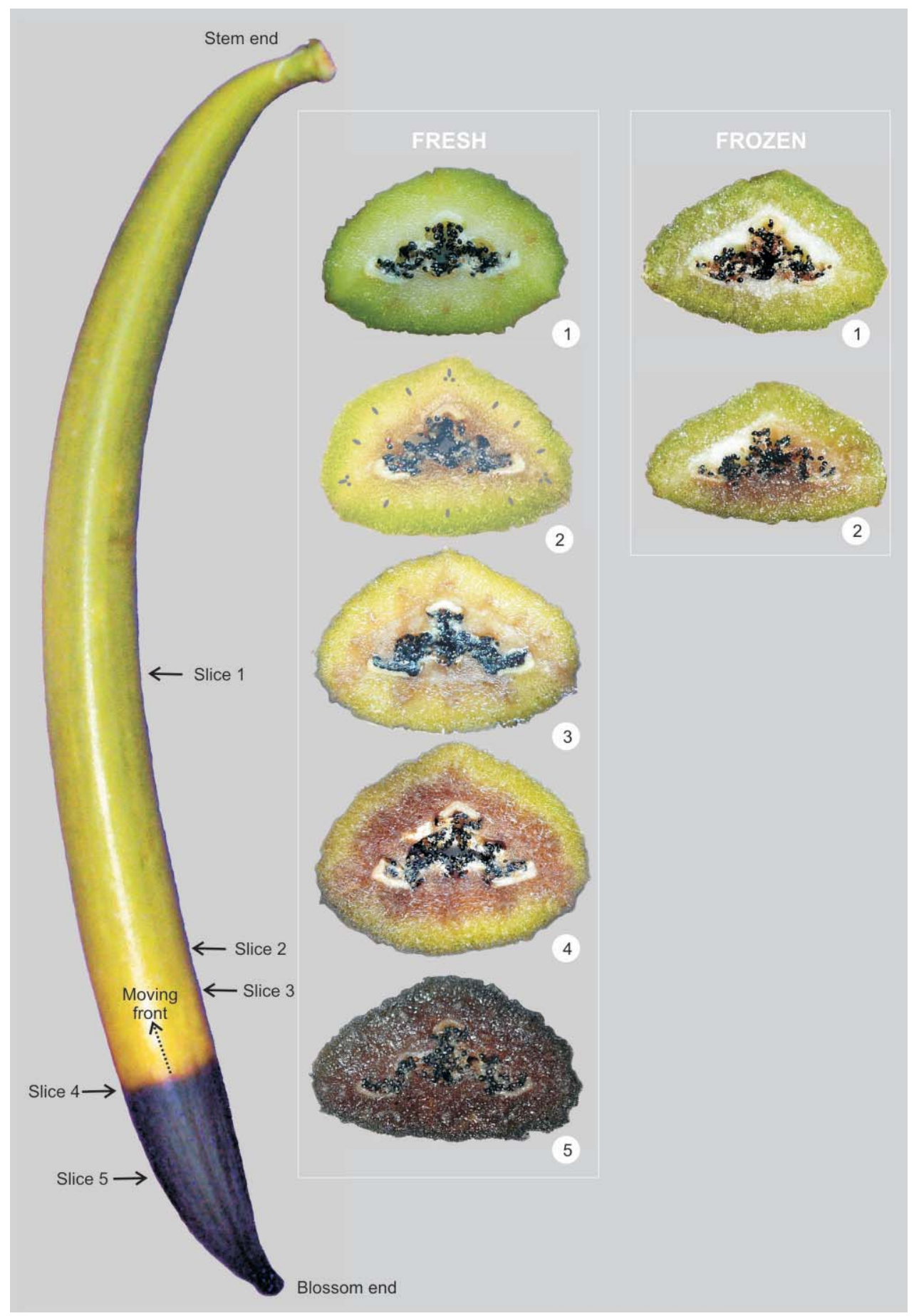

\section{Discussion}

Arana [1, 2] measured the glucovanillin content in three portions of green mature pods (stem region, middle and blossom region; presumably, $1 / 3$ of the length each), and found that glucovanillin mass distribution in these three regions, taking into account their weight proportions, was, in the pod, 20/40/ 40 of the total. We confirm more precisely 


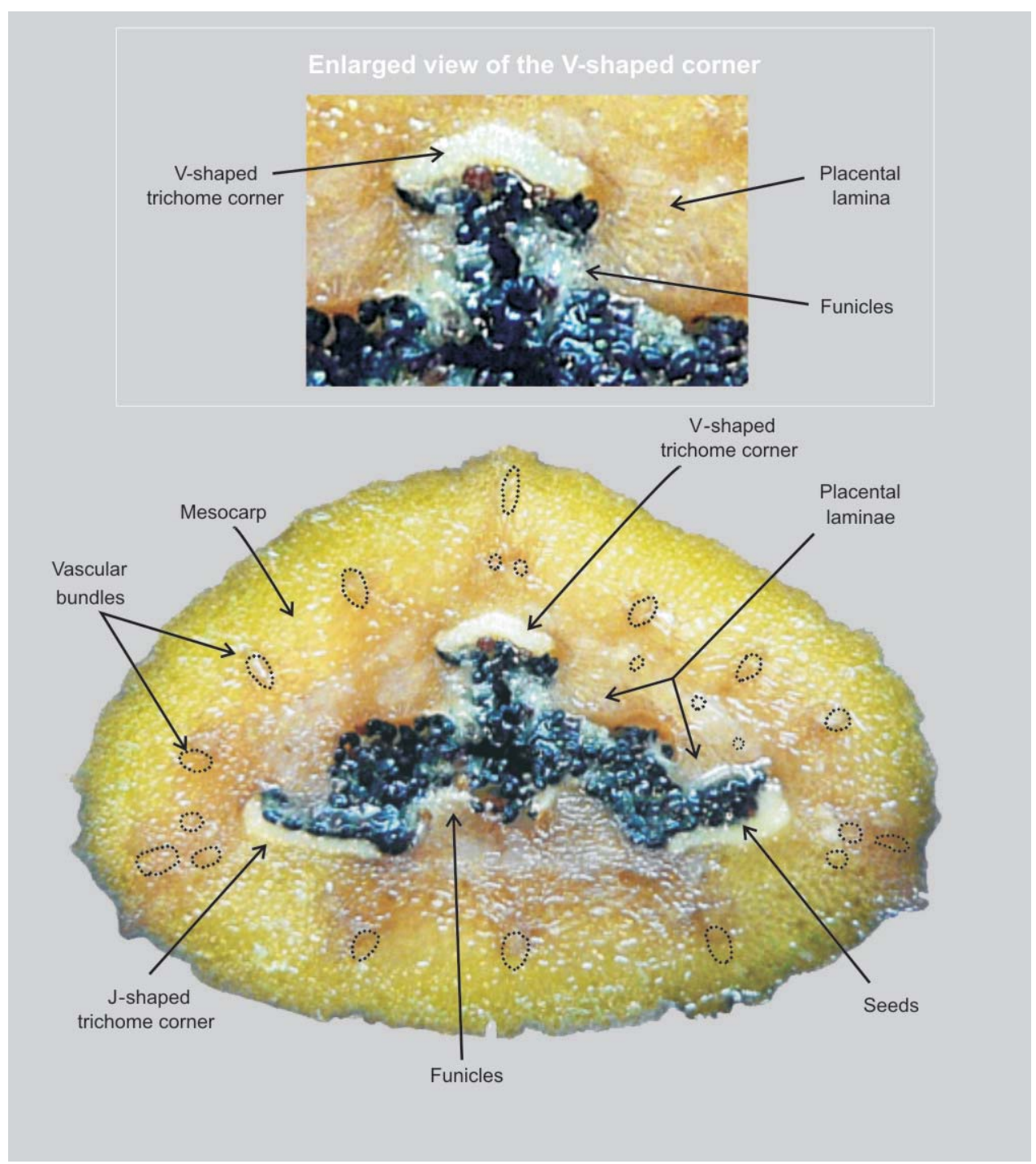

that pronounced gradients exist all along the pods for water, glucovanillin, vanillin, $p$ hydroxy-benzaldehyde glucoside, and its aglycon; the shapes of these gradients much resemble those of mass and dry matter distributions, i.e., negligible levels of phenolics at the stem end, progressively increasing up to pod slice $\mathrm{n}^{\circ} 14$, then decreasing strongly until the floral end. It is noteworthy that sugars followed a symmetrical trend. Coming back like Arana [1] to a 1/3 distribution of the three regions (i.e., stem end: fractions $\mathrm{n}^{\circ} 1$ to 6 ; middle fractions: $\mathrm{n}^{\circ} 7$ to 11 ; and blossom end; fractions $n^{\circ} 12$ to 16 ; figure 2 ), we found, all calculations done, a 17/43/40 distribution for the total phenolics (glucov- anillin being largely dominant), a ratio almost identical to Arana's; this means that the two-thirds of the pod from its apex contain more than $80 \%$ of the total vanillin precursor. It is noteworthy that the $22 / 40 / 38$ distribution for the $\beta$-glucosidase activity is quite similar to the phenolics one.

If one considers the glucovanillin levels expressed as $\mathrm{mM}$ in the water phase of the pod (i.e., $100 \mathrm{mM}$, dry matter basis), one may calculate that its concentration from slice $\mathrm{n}^{\circ} 8$ to slice $\mathrm{n}^{\circ} 15$ (blossom end) equals $\sim 50 \mathrm{mM}$, i.e., $10 \times K_{\mathrm{m}}$ of the vanilla $\beta$-glucosidase in dilute solutions [6], or $2.2 \times K_{0.5}$ of the same enzyme working in heat-treated pods [7]; thus, in the first comparison, this
Figure 5.

Transverse fresh section (pod slice $n^{\circ} 3$ ) from the middle region of a ripening-senescent vanilla pod showing distribution of oxidation. 
Figure 6.

Top: cross-section of a vanilla pod after staining with Nile red (V-shaped trichome corner of the pod; red fluorescing particles are from the chlorophyllous mesocarp). Bottom: autofluorescence.
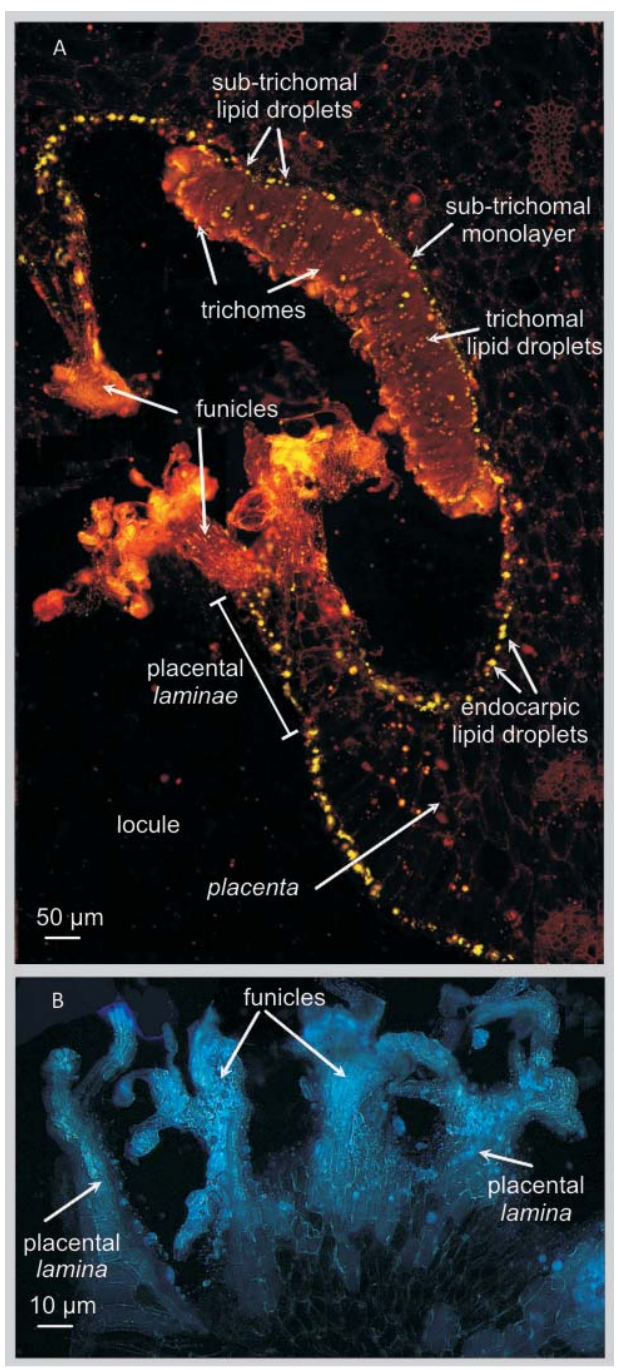

enzyme would work for a while at its $V_{\max }$, while, in the second case, hydrolysis would also proceed at $V_{\max }$, but for a shorter period of time. As in addition to that, the level of the $\beta$-glucosidase activity shows a gradient similar to that of glucovanillin, and although most of this activity is lost upon "killing" [7, 21, 22], the residual enzyme would, at the beginning, work at its maximum speed in the middle-blossom end regions; then, its reaction rate would decrease progressively downwards to the stem end, as its activity level and glucovanillin concentration do.

Both the above observations are thus to be related to the preferential occurrence of vanillin crystals on the epidermis of the middle region and blossom end of cured vanilla pods $[1,2]$. It is also noticeable that a black blossom end-split overripe pod was invaded by mold at the stem end only where vanillin, presumably toxic to some fungal species [23], is present at trace level [pers. com.].

Considering the peroxidase and $\beta$-glucosidase gradient shapes, one understands now why, as long as sufficient vanillin is liberated by the $\beta$-glucosidase at the blossom end where peroxidase is very high, oxidation starts in this portion by forming blossom-end-yellow pods (figure 4) $[1,10]$. The determinism of this preferential oxidation at the floral end must be searched for in the structure and anatomy of the pod: vascular bundles, comprising xylem vessels, run its whole length from the stem to the floral pieces. They are present in a constant number of 27 (figures 4, 5 and ref. [20]) distributed as follows: in the mesocarp $-3 \times 3$ (medium diameter; sides of the triangular section) plus 3 (large diameter; corners) and 3 twin (small diameter; corners); in the placental bases $-3 \times 3$ (small diameter; sides of the triangular section). Since the volume occupied by these elements is constant along the pod, and because both ends of the pod have much more reduced diameters than the rest of it, then the volume (weight) proportions of xylem elements in these tissues increase there to the detriment of parenchyma (number and/or size of cells); conversely, in the pseudo-cylindrical portion (slices $n^{\circ} 7$ to 5), the ratio (xylem/parenchyma) is constant, and so is the peroxidase activity. Since cell wall-bound [24] and soluble peroxidases [25] are known to play a role in the lignification of secondary walls of the xylem by converting the monolignols (coumaryl, coniferyl and synapyl alcohols) into free radicals which spontaneously polymerize to give lignin, one may hypothesize that xylem peroxidase(s) is somewhat involved in vanillin oxidation; however, the existence of other non-vascular peroxidases cannot be ruled out (see below). Since glucovanillin, and thus vanillin and $\beta$-glucosidase are very low in the very stem end, and although peroxidase is, as at the blossom end, higher than in the central core, oxidation does not develop there. 
The progressive longitudinal invasion of vanillin oxidation from the blossom to the stem ends (see below) is also well explained by these gradients: indeed, glucovanillin is not prone to oxidation due to engagement of its vanillin phenoxy group in the $\beta$-glucosidic linkage, while free vanillin is; thus, action of the $\beta$-glucosidase is a prerequisite to oxidation, and since its level decreases continuously from slice $n^{\circ} 14$ downwards to the stem end, the amount of vanillin liberated per unit of time will also decrease, and, thus, the browning front will progressively move to the stem end, i.e., the length of time to get from green to yellowish to chocolate brown will increase.

The anatomical distributions of glucovanillin and $\beta$-glucosidase were first shown by Odoux et al. [11]; the same authors later gave a more detailed analysis of the repartition of phenolics in the green mature pods [13]. We give here an even more complete anatomical picture and a quantitative analysis of the distributions of the $\beta$-glucosidase and peroxidase activities in a representative slice, the peroxidase repartition having, to our knowledge, never been published (figure 3, table I). $\beta$-glucosidase, as formerly shown [13], is high in the placentae whatever the portion considered, and lower in the mesocarp and trichomes; again, one must point out the uselessness of this enzyme, at least at the beginning of hydrolysis, in the green glucovanillin-free mesocarp, contrary to the assertion of Arana [1]. Peroxidase is far higher in the mesocarp than in placentae, and was not detected in the trichome strips [13]; according to the fresh matter distribution of the two compartments [13], it is thus essentially found in the mesocarp. This result is not surprising since, as mentioned above, the mesocarp contains most of the pod vascular bundles including xylem vessels. Ironically, the mesocarp does not contain oxidizable phenols (e.g., vanillin), but likely only those serving as substrates for lignin synthesis (e.g., p-coumaric acid) which are encountered in xylem vessels [26]. Placentae also include vascular bundles of small diameter and, per placental pair, two of them are located at the base of each placental lamina, one of them in between (figures 4, 5 and ref. [20]). However, and since oxidation seems homogeneous in placental laminae (figure 4 , frozen slice $\mathrm{n}^{\circ} 2$, upper right), i.e., there is no preferential oxidation surrounding the bundles, one may imagine that placental peroxidase(s) would not be only restricted to the xylem, but would also be of parenchymatous origin. Indeed, plant peroxidases have been, for instance, also encountered in vacuoles [27]. Dignum et al. studied the stability of vanilla peroxidase in crude extracts [16], and Márquez et al. recently purified from whole pods with yellow apices a cell wall-bound peroxidase from vanilla pod [17]. However, the fine localization of peroxidases in the pod and their status (cell wall-bound, and possibly soluble forms) is not yet known.

When examining the progression of oxidation along the longitudinal axis of pods, one may define successive steps:

- in the green parts, enzymatic hydrolysis of glucovanillin did not begin, and only some mesocarpic xylem vessels show, after section, signs of oxidation, likely of the phenyl-propanoids by the xylem peroxidase(s),

- when considering the blossom end, one may see that oxidation, in addition to the above observation, concerns the whole placental laminae only, i.e., the mesocarpic parenchyma is not involved. Indeed, at this stage, glucovanillin only present in the placentae and trichomes undergoes progressive hydrolysis with liberation of vanillin itself undergoing enzymatic oxidation in the placentae; at that time, the incompleteness of hydrolysis is visible in residual whitish placental areas,

- later on, oxidation progressively invades the inner mesocarp, drawing radiating shapes of coalescence with the mesocarpic xylem oxidation zones,

- oxidation develops further into a concentric annulus comprising half of the mesocarp surface, and the coloration intensity increases, which indicates the completeness of glucovanillin hydrolysis and further subsequent oxidation of vanillin,

- finally, oxidation products spread all over the pod section, and the color turns from reddish to chocolate brown. 


\section{J.M. Brillouet et al.}

Thus, it is now possible to draw a hypothetical scheme of events leading to the brown-blackish vanilla pod (figure 7):

- when ripening on the vine or during the traditional curing process, a tissular decompartmentation occurs [5], and phenolic $\beta$-glucosides and $\beta$-glucosidase become present,

- hydrolysis of glucovanillin and other glucoconjugates by the $\beta$-glucosidase begins in the placentae, and the presence of this enzyme in the mesocarp serves, at that time, no use; vanillin and other aglycons are released, and the whitish zone slowly disappears,

- rapidly or simultaneously, oxidation of these phenolics develops only in the placentae where substrates and peroxidase(s) are present; the mesocarp is not concerned, except its xylem vessels,

- reddish then brown oxidation products diffuse outwards into the inner mesocarp; however, the possibility that glucovanillin and/or vanillin migrate into the mesocarp and also undergo hydrolysis and oxidation there cannot be ruled out; nevertheless, one must recall that placentae have by far enough $\beta$-glucosidase for glucovanillin to be hydrolyzed in situ without diffusing into another compartment [11, 13, this work]. At that moment, it is important to recall the comment of Arana [1] on the prerequisite for glucovanillin to diffuse from the inner placental parts of the pods outwards to the mesocarp for being hydrolyzed by the $\beta$-glucosidase: actually, we show here that this sequence of events is not compulsory but may or may not happen. It is presumably the oxidation products accompanied or not by glucovanillin and vanillin which diffuse into the mesocarp. Indeed, the possibility that vanillin would also be oxidized by the mesocarp xylem peroxidase(s) cannot be ruled out. Until peroxidase activity is precisely localized in the mesocarp (vascular bundles and parenchyma?), this question remains open,

- finally, the whole pod turns deep brown, then blackens upon drying.

A particular point must be emphasized: throughout the ripening-ageing period when pods turn from green to black, the trichomes and funicles, although sources of glucovanillin and $\beta$-glucosidase (table I and

\section{Figure 7.}

Sequence of some consecutive enzymatic and chemical reactions occurring at the vanillin level in the vanilla pod.

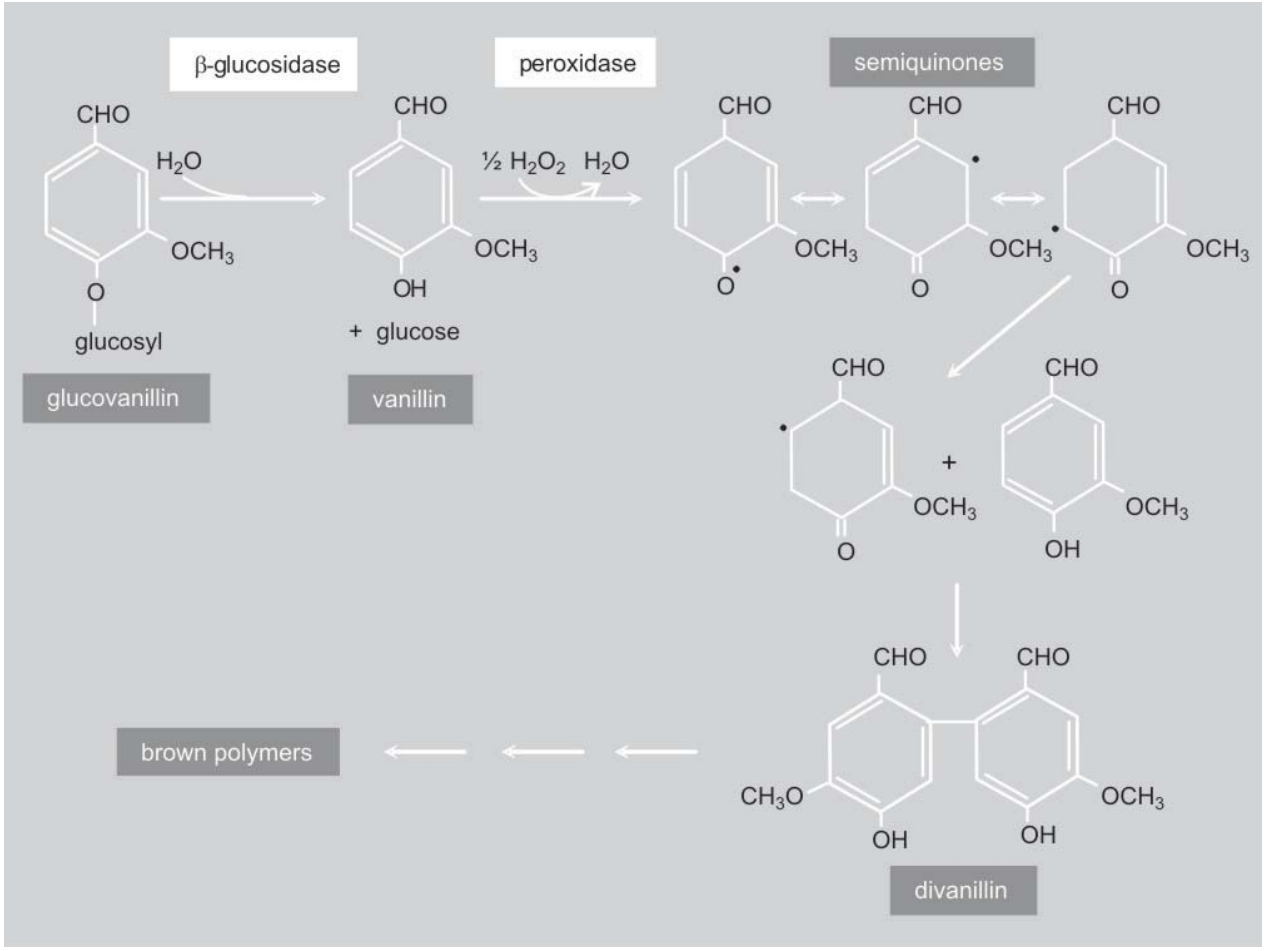


refs. [11, 13]), do not show oxidation and remain whitish and glassy until late. This is to be related to the absence of peroxidase and also to their richness in lipids (figure 3 and refs.[13, 28]); as formerly mentioned [13], the absence of catechin- $\mathrm{HCl}$ staining of vanillin-containing trichomes [12] was likely due to the presence of high quantities of lipid reserves in this compartment. The constitution of trichome lipids is now partly defined ( $\gamma$-pyranones) [13], while the funicular ones remain unknown.

Finally, we also found that the "total" vanillin content, actually close to the glucovanillin concentration [3], of green vanilla pods was quite variable amongst a population: thus, to characterize a batch or follow maturation kinetics, one has to take into account this variability and carry out measurements on a sufficient number of pods. The same observation was true for the $\beta$-glucosidase activity, one of the key enzymes in the development of the vanilla aroma: it was variable amongst a population of pods of the same physiological age and origin. This is also likely true for a given set of vines from one year to another, depending on the climatic conditions of culture. Again, one must be cautious and analyze numerous pods before giving an amount of activity per unit of fresh weight.

\section{Conclusion}

Green mature vanilla pods are heterogeneous along their longitudinal axis, exhibiting pronounced gradients of decreasingincreasing concentrations of water, and increasing-decreasing ones of $\beta$-glucosidase and phenolics from the stem to the floral end; peroxidase activity is differently distributed, stable in a major portion of the pod and increasing at its two ends. These elements are also heterogeneously distributed in the vanilla pod tissues, phenolics and $\beta$ glucosidase being preponderant in the placentae while peroxidase predominates in the mesocarp. Finally, oxidation of phenols develops from the placental region of the blossom end towards the stem end; then the oxidation products (brown pigments) progressively invade the mesocarp and, in the end, the whole pod.

Green mature vanilla pods are variable for their glucovanillin and $\beta$-lucosidase contents, which must be taken into account in studies devoted to these components.

\section{Acknowledgements}

We thank M. Bourgois (Eurovanille, France) and Dr. K. Waliszewski (Inst. Tecnol., Veracruz, Mexico) for gifts of Indian and Mexican vanilla pods, respectively. Thanks are also due to G. Morel (CIRAD-PERSYST) for his helpful assistance in HPLC analyses.

\section{References}

[1] AranaF.E., Action of a $\beta$-glucosidase in the curing of vanilla, Food Res. 288 (1943) 343-351.

[2] Arana F.E., Vanilla curing and its chemistry, in: USDA Bull. Fed. Exp. Stn, Mayaguez, Puerto-Rico, No. 42, 1944, pp. 1-17.

[3] Odoux E., Changes in vanillin and glucovanillin concentrations during the various stages of the process traditionally used for curing Vanilla fragrans in Réunion, Fruits 55 (2000) 119-125.

[4] Dignum M.J.W., Kerler J., Verpoorte R., Vanilla production: technological, chemical, and biosynthetic aspects, Food Rev. Int. 17 (2001) 199-219.

[5] Odoux E., Escoute J., Verdeil J.-L., The relation between glucovanillin, $\beta$-glucosidase activity and cellular compartmentation during the senescence, freezing and traditional curing of vanilla beans, Ann. Appl. Biol. 149 (2006) 43-52.

[6] Odoux E., Chauwin A., Brillouet J.-M., Purification and characterization of vanilla bean (Vanilla planifolia Andrews) $\beta$-D-glucosidase, J. Agric. Food Chem. 51 (2003) 3168-3173.

[7] Brillouet J.-M., Odoux E., In vivo kinetics of $\beta$-glucosidase towards glucovanillin and related phenolic glucosides in heat-treated vanilla pod (Vanilla planifolia; Orchidaceae), Fruits 65 (2010) 85-95. 
[8] Jones M.A., Vicente G.C., Criteria for testing vanilla in relation to killing and curing methods, J. Agric. Res. 78 (1949) 445-450.

[9] Jones M.A., Vicente G.C., Quality of cured vanilla in relation to some natural factors, J. Agric. Res. 78 (1948) 425-434.

[10] Krishnakumar V., Bindumol G.P., Potty S.N., Govindaraju C., Processing of vanilla (Vanilla planifolia Andrews) beans - Influence of storing fresh beans, killing temperature and duration of killing on quality parameters, J. Spices Aromat. Crops 16 (2007) 31-37.

[11] Odoux E., Escoute J., Verdeil J.-L., Brillouet J.-M., Localization of $\beta$-glucosidase activity and glucovanillin in vanilla bean (Vanilla planifolia Andrews), Ann. Bot. 92 (2003) 437-444.

[12] Joel D.M., French J.C., Graft N., Kourteva G., Dixon R.A., Havkin-Frenkel D., A hairy tissue produces vanillin, Isr. J. Plant Sci. 51 (2003) 157-159.

[13] Odoux E., Brillouet J.-M., Anatomy, histochemistry and biochemistry of glucovanillin, oleoresin and mucilage accumulation sites in green mature vanilla pod (Vanilla planifolia; Orchidaceae): a comprehensive and critical reexamination, Fruits 64 (2009) 221-241.

[14] Wild-Altamirano C., Enzymic activity during growth of vanilla fruit. I. Proteinase, glucosidase, peroxidase and polyphenoloxidase, J. Food Sci. 34 (1969) 235-238.

[15] Hanum T., Changes in vanillin and activity of $\beta$ $D$-glucosidase and oxidases during post harvest processing of vanilla beans (Vanilla planifolia), Bull. Tecknol. Ind. Pagan 8(1997) 46-52.

[16] Dignum M.J.W., Kerler J., Verpoorte R., $\beta$ glucosidase and peroxidase stability in crude enzyme extracts from green beans of Vanilla planifloia Andrews, Phytochem. Anal. 12 (2001) 174-179.

[17] Márquez O., Waliszewski K.N., Oliart R.M., Pardio V.T., Purification and characterization of cell-wall bound peroxidase from vanilla bean, Lebens. Wiss. U-Technol. 41 (2008) 1372-1379.

[18] Gatfield I., Rei $\beta$ I., Krammer G., Schmidt C.O., Kindel G., Bertram H.-J., Divanillin, novel taste-active component of fermented vanilla beans - The elucidation of the fate of vanillin during the traditional curing process, Perfumer \& Flavorist 31 (2006) 18-20.

[19] Dignum M.J.W., van der Heijden R., Kerler J., Winkel C., Verpoorte R., Identification of glucosides in green beans of Vanilla planifolia Andrews and kinetics of vanilla $\beta$-glucosidase, Food Chem. 85 (2004) 199-205.

[20] Roux P., Études morphologiques et anatomiques dans le genre Vanilla, in: Bouriquet $G$. (Ed.), Le vanillier et la vanille dans le monde, Lechevalier, Paris, France, 1954, pp. 44-92.

[21] Dignum M.J.W., Kerler J., Verpoorte R., Vanilla curing under laboratory conditions, Food Chem. 79 (2002) 165-171.

[22] Perez Silva A., Contribution à l'étude de la genèse des composés d'arôme au cours du procédé mexicain de transformation de la vanille (Vanilla planifolia Jackson), Univ. Montpellier II, PhD Thesis, Montpellier, France, 2006.

[23] Stentelaire C., Lesage-Meesen L., Oddou J., Bernard O., Bastin G., Colonna Ceccaldi B., Asther M., Design of a fungal bioprocess for vanillin production from vanillic acid at scalable level by Pycnoporinus cinnabarinus, J. Biosci. Bioeng. 89 (2000) 223-230.

[24] López-Serrano M., Fernández M.D., Pomar F., Pedreño M.A., Ros Barceló A., Zinnia elegans uses the same peroxidase isoenzyme complement for cell wall lignifications in both single-cell tracheary elements and xylem vessels, J. Exp. Bot. 55 (2004) 423-431.

[25] Christensen J.H., Bauw G., Welinder K.G., van Montagu M., Boerjan W., Purification and characterization of peroxidases correlated with lignification in poplar xylem, Plant Physiol. 118 (1998) 125-135.

[26] Suzuki S., Sakakibara N., Li L., Umezawa T., Chiang V.L., Profiling of phenylpropanoid monomers in developing xylem tissue of transgenic aspen (Populus tremuloides), J. Wood Sci. (2009) DOI 10.1007/s10086009-1059-8.

[27] Passardi F., Cosio C., Penel C., Dunand C., Peroxidases have more function than a Swiss army knife, Plant Cell Rep. 24 (2005) 255-265.

[28] French J.C., Development of vanilla-bearing placental trichomes, in: Proc. Vanilla, First Int. Congr., Princeton, USA, Carol Stream, Allured Publ. Corp., USA, 2005, pp. 71-77. 
Conjunto de resultados sobre la vaina de vainilla verde, en proceso de maduración y sensescente (Vanilla planifolia; Orchidaceae): anatomía, encimas, compuestos fenólicos y lípidos.

Resumen - Introducción. Las vainas de vainilla verdes maduras acumulan 4-O-(3-metoxibenzaldebído)- $\beta$-D-glucósido (glucovainilla) que, bajo el efecto de una hidrólisis mediante una $\beta$-glucosidasa endógena, libera vainillina, el principal compuesto de aroma de la vainilla. Las reparticiones espaciales de los compuestos fenólicos generadores de aroma y de las encimas responsables de su liberación ( $\beta$-glucosidasa) y oxidación (peroxidasa) son poco conocidas. A continuación ofrecemos resultados cuantitativos de estos tres compuestos en relación con la anatomía de la vaina. Asimismo, se ilustrará la progresión espacial de la oxidación. Material y métodos. Se analizaron vainas de vainilla verdes maduras para su contenido en compuestos fenólicos y actividades $\beta$-glucosidasa y peroidasa mediante técnicas espectrofotométricas, gracias al empleo respectivo de glucósido de $p$-nitrofenilo y de vainilla como sustratos. Los lípidos se examinaron en microscopía fluorescente tras coloración roja de Nil. El desarrollo de la oxidación se observó en cortes transversales de vainas. Resultados y discusión. Los compuestos fenólicos, así como las actividades $\beta$-glucosidasa y peroxidasa muestran gradientes de concentraciones crecientes-decrecientes de la extremidad peduncular hacia la extremidad floral de la vaina. La actividad $\beta$-glucosidasa se distribuye entre placentas, mesocarpio y tricomas con una relación [7 / $2 / 1]$, mientras que la actividad peroxidasa se reparte en proporciones [38 / 1] entre el mesocarpio y las placentas; está ausente de tricomas. La oxidación empieza en las placentas de la parte floral invadiendo progresivamente el mesocarpio y se desplaza hacia la zona peduncular. Conclusión. La vaina de vainilla verde madura es heterogénea desde un punto de vista espacial en lo que se refiere a sus compuestos fenólicos y actividades $\beta$-glucosidasa y peroxidasa, las placentas desempeñan un papel importante en la liberación de la vainillina y en su oxidación consecutiva.

Francia / Vanilla planifolia / Orchidaceae / vainilla / $\beta$-glucosidasa / peroxídasas / glucovanillina / vanillina / lípidos / oxidación / mesocarpio / placentas / tricomas / xilema 